\title{
PHENOLOGICAL OBSERVATIONS OF SELECTED SPECIES FROM THE GENUS SYRINGA L. (OLEACEAE) IN THE BOTANICAL GARDEN OF THE ADAM MICKIEWICZ UNIVERSITY IN POZNAŃ
}

\author{
Mateusz Sowelo, Wojciech AntKowiak
} M. Sowelo, W. Antkowiak, Department of Botany, Poznań University of Life Sciences, Wojska Polskiego 71 C,
60-625 Poznań, Poland, e-mail: antkowiak@up.poznan.pl

(Received: June 27, 2017. Accepted: August 21, 2017)

\begin{abstract}
Phenological observations at the Botanical Garden of the Adam Mickiewicz University in Poznań were conducted on Syringa komarowii, S. meyeri, S. microphylla, S. oblata, S. reticulata, S. tomentella and S. wolfii. These observations showed the longest foliation phase in the case of S. oblata and S. meyeri, while the longest flowering phase was recorded in S. reticulata, S. microphylla and S. wolfii. Additionally, the longest period of anthesis (i.e. the period from the moment when $25 \%$ flowers bloomed to the time when $75 \%$ were out of bloom) was observed in S. oblata and S. microphylla. All examined shrubs, except for S. oblata, set fruits, which dispersal was extended to the next year (except for S. komarowii). In terms of decorative value suitable for green areas the most valuable species were S. komarowii, S. reticulata, S. meyeri, S. microphylla and S. oblata, with the three latter being the most showy shrubs in terms of autumn foliage. Moreover, S. komarowii was exceptional among the analysed species due to its large, attractive leaf blades. This lilac, together with S. meyeri, was also characterised by the most decorative inflorescences. Thanks to their stronger growth in comparison to the other species, S. komarowii, S. oblata and S. reticulata are best suited for large gardens, whereas S. meyeri and S. microphylla will prove most suitable for small gardens. All the recommended shrubs show good drought resistance.
\end{abstract}

KEY WORDS: seasonal rhythm, climate factors

\section{INTRODUCTION}

Among approximately 30 lilac species only a few are known and common in green areas. This is evidenced e.g. by the offer of plants provided by the Polish Nurserymen Association (http://www.zszp. $\mathrm{pl} /$ ), predominantly common lilac (Syringa vulgaris) with its cultivars, while other species: $S$. Xchinensis, S. Xhyacinthifolia, S. meyeri, S. microphylla, S. oblata, S. patula and S. protolancinata, are represented in small numbers. Most species from that genus exhibit adequate frost resistance to be grown throughout Poland (BiazoboK \& Hellwig 1955, Bugaza 2000). However, before they may be used more extensively sufficient information needs to be gathered on those species and it may be provided e.g. by phenological observations (EUKASIEWICZ 1984). Reliable observations yield detailed data on the duration of specific elements of decorative value, such as flowering or foliation, in- cluding leaf autumn colour change (BieLAWsKa et al. 1964, ВіАєОВок 1971). It is particularly important when selecting plants and designing multispecies arrangements characterised by a sequence of flowering of used taxa. Additionally, according to CHYLARECKI \& Straus (1968) and WitKowsKa (1984) it is crucial to gain information on the complete generative cycle of a given plant, as it is an indicator of vigour and the degree of adaptation to specific environmental conditions at a given locality.

The use of lilacs in green areas may vary and be dependent on the species, since they differ, among other things, in their habit and growth. They are suitable for parks, squares and roadside belts, home gardens or allotment plots. They work very well when used singly, e.g. S. komarowi or S. wolfi, and in clusters - bot single- and multi-species. In turn, S. meyeri and S. microphylla are better suited for home gardens and allotment plots (Віаєовок \& Hellwig 1955, ŁUKASIEWICZ 1995, NAWrocka-GrZeśKOWIAK 
1997, Bugata 2000, Bąbelewski 2009, Seneta \& DolaTOWSKI 2012, CZEKALSKi 2014).

The aim of this study was to conduct phenological observations on selected lilac species from the collection of lilacs from the Botanical Garden of the Adam Mickiewicz University in Poznan and on this basis propose taxa best suited for urban conditions and of greatest value in terms of their use in green areas.

\section{THE STUDY AREA, MATERIAL AND METHODS}

Phenological observations were performed at the Botanical Garden of the Adam Mickiewicz University in Poznań from March to December 2015. Analyses were conducted on seven lilac species: Syringa komarowii C.K. Schneid. (register no. 691), S. meyeri C.K. Schneid. (no. 2939), S. microphylla Diels (7517), S. oblata Lindl. (3766), S. reticulata (Blume) H. Hara (835), S. tomentella Bureau \& Franch. (2376) and S. wolfii C.K. Schneid. (439). According to BugatA (2000) and TAKHTAJAN (2009), they belong to the subgenus Ligustriana (S. reticulata) and Syringa, within which the analysed lilacs may be allocated to sections Villosae (S. komarowii, S. wolfii) and Syringa (S. meyeri, S. microphylla, S. oblata, S. tomentella).

Observations were conducted on one shrub from each species, except for $S$. reticulata, which register number is allocated to two shrubs planted at a very small distance from each other, as a result of which they form one common crown. Dates of phenologi- cal parameters were recorded with varying frequency, depending on the developmental phase of plants. Flower development was examined four times a week. Observations of the individual phases of vegetative development and fruits were conducted with a minimum frequency of twice a week.

The distribution of examined plants in the Botanical Garden is given in Figure 1.

Research methods were adopted after ŁuKASIEWICZ (1984). In order to illustrate the results phenological spectra were prepared using the method developed by SCHENNIKOV (1928) as modified by ŁuKASIEWICZ (1984). The following leaf development phases were observed:

1. onset of leaf bud break

2. onset of leaf blade opening (the first leaves unfold their blades and their adaxial surface is visible)

3. onset of autumn leaf colour change (marked change in approx. $10 \%$ leaves)

4. onset of full autumn leaf colour change (approx. $50 \%$ autumn foliage)

5. end of full autumn leaf colour change (approx. $90 \%$ autumn foliage)

6. loss of decorative autumn foliage

7. onset of leaf fall

8. end of leaf fall (all leaves have been shed or only single leaves are left).

Flower development phases:

9. appearance of first flower or inflorescence buds

10. blooming of first flowers (several first flowers fully open)

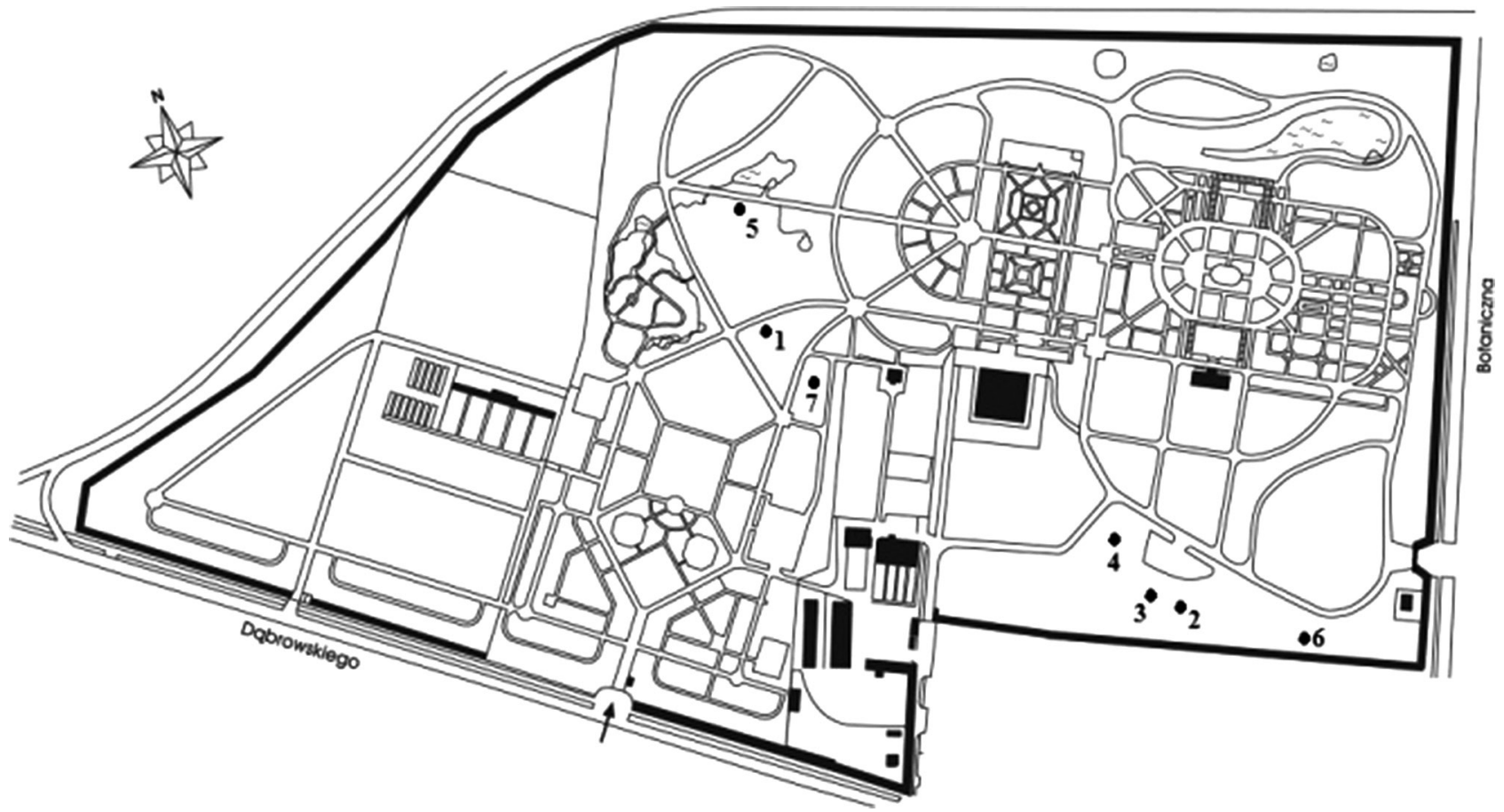

Fig. 1. The plan of the Botanical Garden of the Adam Mickiewicz University in Poznan with the distribution of analysed lilac species: 1 - S. komarowii, 2 - S. microphylla, 3 - S. meyeri, 4 -S. oblata, 5 - S. reticulata, 6 - S. tomentella, 7 - S. wolfi (https://omp.oop.org.pl/ogrody/ogrod-botaniczny-w-poznaniu/) 
11. onset of anthesis (approx. 25\% flowers in bloom; onset of mass flowering)

12. first flowers out of bloom (onset of first unripe fruits)

13. end of full anthesis (approx. $75 \%$ flowers out of bloom; end of the effect of mass flowering)

14. last flower buds

15. end of flowering (date when the last flowers are out of bloom).

Fruit development phases:

16. onset of fruit ripening (the first fruits change colour and texture)

17. onset of full fruit ripening (approx. 50\% fruits take colour and texture characteristic of that phase)

18. end of fruit ripening (all fruits have ripened)

19. onset of fruit dispersal (the first fruits or seeds start to fall)

20. full fruit dispersal (approx. 50\% fruits and seeds have been shed)
21. end of fruit dispersal (all or almost all fruits or seeds have been shed).

\section{Climatic conditions}

Meteorological data were collected from the Marcelin Experimental Station (Zgorzelecka 4 Street) of the Poznań University of Life Sciences. Measurements, on the basis of which ombrothermic diagrams according to Gaussen and Walter were prepared, are given in Tables 1 and 2. Dates for the onset of phenological seasons in Poznań from the Institute of Meteorology and Water Management, the National Research Institute, were collected from observations recorded at the Poznań Ławica station. Additionally, the winter period was identified after ŁUKASIEWICZ \& GóRSKA-ZAJĄCZKOWSKA (1983), with its onset established at three successive days with maximum air temperatures below $0^{\circ} \mathrm{C}$. These data are given in Table 3 and they were used as the background for the graphic presentation of research results.

Table 1. Weather data for the year of observations and the decade preceding the study

\begin{tabular}{ccccc}
\hline \multirow{2}{*}{ Month } & \multicolumn{2}{c}{ Mean temperature $\left({ }^{\circ} \mathrm{C}\right)$} & \multicolumn{2}{c}{ Precipitation total $(\mathrm{mm})$} \\
\cline { 2 - 5 } & $2005-2014$ & 2015 & 32.7 & 34.0 \\
I & -1.0 & 1.9 & $2005-2014$ & 7.6 \\
II & -0.2 & 1.2 & 31.6 & 43.2 \\
III & 3.6 & 5.5 & 25.9 & 18.0 \\
IV & 10.2 & 8.5 & 56.1 & 27.2 \\
V & 14.2 & 13.3 & 54.9 & 93.6 \\
VI & 17.5 & 15.9 & 79.3 & 86.6 \\
VII & 20.2 & 19.4 & 52.5 & 23.6 \\
VIII & 18.5 & 22.5 & 34.6 & 21.8 \\
IX & 14.7 & 14.7 & 23.8 & 19.2 \\
X & 9.2 & 8.0 & 36.5 & 5.4 \\
XI & 5.0 & 6.1 & 31.5 & - \\
XII & 0.7 & 5.7 & - & 22.6 \\
Mean & 9.4 & 10.2 & 481.4 & - \\
Total & - & - & & 402.8 \\
\hline
\end{tabular}

Table 2. Extreme and mean minimum and maximum temperatures in $2015\left({ }^{\circ} \mathrm{C}\right)$

\begin{tabular}{|c|c|c|c|c|c|c|c|c|}
\hline \multirow[b]{2}{*}{ Month } & \multicolumn{4}{|c|}{ 2005-2014 } & \multicolumn{4}{|c|}{2015} \\
\hline & 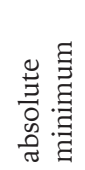 & 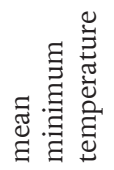 & 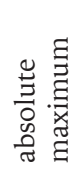 & 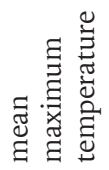 & 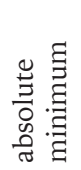 & 茎莺 & 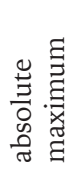 & 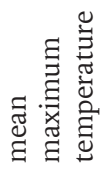 \\
\hline I & -14.4 & -3.4 & 8.2 & 1.2 & -6.9 & -0.1 & 12.2 & 4.0 \\
\hline II & -11.5 & -2.9 & 10.2 & 2.4 & -8.3 & -2.0 & 10.0 & 4.4 \\
\hline III & -7.6 & -0.4 & 16.1 & 7.5 & -5.2 & 1.1 & 17.3 & 10.0 \\
\hline IV & -1.7 & 4.9 & 24.3 & 15.4 & -2.8 & 2.9 & 24.9 & 13.8 \\
\hline $\mathrm{V}$ & 1.2 & 8.7 & 28.1 & 19.2 & 0.3 & 6.9 & 25.0 & 18.7 \\
\hline VI & 6.1 & 12.0 & 31.4 & 22.5 & 5.2 & 10.2 & 31.7 & 21.5 \\
\hline VII & 10.1 & 15.1 & 33.1 & 25.6 & 8.1 & 13.5 & 34.4 & 25.2 \\
\hline VIII & 7.6 & 13.5 & 31.1 & 23.6 & 6.7 & 15.9 & 36.5 & 28.8 \\
\hline IX & 3.6 & 10.1 & 27.0 & 19.6 & 2.8 & 9.6 & 34.3 & 20.6 \\
\hline $\mathrm{X}$ & -1.9 & 5.5 & 20.8 & 13.6 & -1.4 & 4.4 & 21.4 & 12.2 \\
\hline XI & -3.8 & 2.6 & 15.9 & 7.9 & -4.4 & 2.9 & 15.7 & 9.4 \\
\hline XII & -8.8 & -1.6 & 9.2 & 2.8 & -5.7 & 3.3 & 13.9 & 8.0 \\
\hline
\end{tabular}


Table 3. Phenological seasons in Poznań in 2015

\begin{tabular}{lllc}
\hline \multicolumn{1}{c}{ Phenological season } & \multicolumn{1}{c}{ Indicator plant/weather } & \multicolumn{1}{c}{ Phase/temperature $\left({ }^{\circ} \mathrm{C}\right)$} & Onset date \\
\hline Beginning of spring & $\begin{array}{l}\text { Corylus avellana L. } \\
\text { Tussilago farfara L. }\end{array}$ & beginning of flowering & 1.03 \\
Early spring & $\begin{array}{l}\text { Prunus padus L. } \\
\text { Taraxacum officinale F.H. Wigg. }\end{array}$ & beginning of flowering & 18.04 \\
& Syringa vulgaris L. & beginning of flowering & 30.04 \\
& Aesculus hippocastanum L. & & \\
Full spring & Robinia pseudoacacia L. & beginning of flowering & 23.05 \\
Early summer & Tilia cordata Mill. & beginning of flowering & 9.06 \\
Summer & Corylus avellana L. & fruit ripening & 6.09 \\
& Aesculus hippocastanum L. & fruit ripening & \\
Autumn & Calluna vulgaris L.) Hull & beginning of flowering & 8.10 \\
& Aesculus hippocastanum L. & leaf yellowing & leaf yellowing and leaf fall \\
Tilia cordata Mill. & leaf yellowing and leaf fall & $3.01^{*}$ \\
\hline
\end{tabular}

* Phenological winter started in 2016.
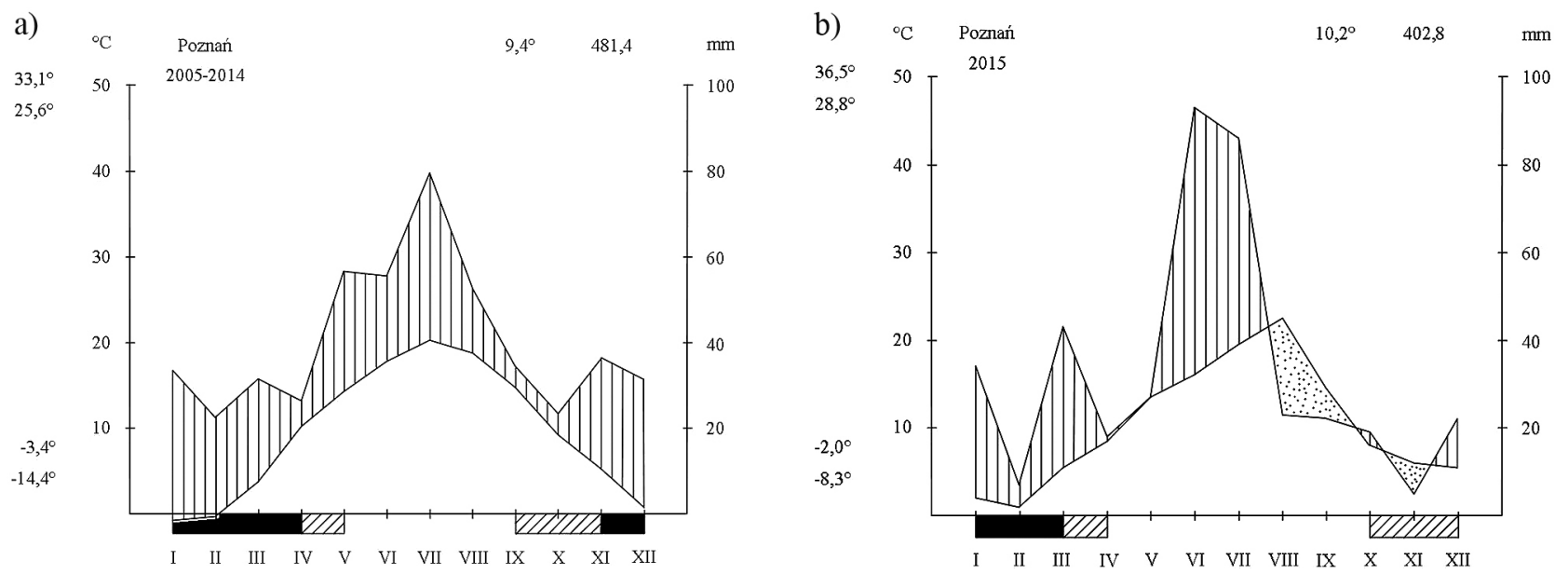

Fig. 2. The ombrothermic diagram according to Gaussen-Walter for the period of 2005-2014 (a) and for 2015 (b)

Analysis of climatic conditions indicates a warmer winter and summer, particularly in August, and a cooler spring of 2015 in relation to mean temperatures for the decade of 2005-2014. Drought lasted from August to the end of November, with only a short wet spell in October, i.e. the precipitation line is below the line plotted for temperature (Fig. $2 b$ ). The mean for the last decade (Fig. 2a) indicates solely a humid period. Thus the periodical drought is not a cyclic aspect and its occurrence provides an opportunity for additional observations of plants under stress conditions.

\section{RESULTS}

Results of phenological studies are given in Tables 4-6. Additionally, they were illustrated with phenological diagrams (Fig. 3).

\section{DISCUSSION}

Syringa oblata was the first of the observed lilacs to bloom, while $S$. reticulata was the last. Similar results were given in her study by Przybora (1980). Also Bugata (2000) indicated S. oblata as an early species and $S$. reticulata as a late species in terms of blooming in comparison to S. vulgaris. This aspect is of great value both for landscape architects and amateur gardeners. Planting arrangements may be designed comprising several lilac species, as a result being very attractive thanks to the considerably extended overall flowering period.

Among the observed species S. oblata was the only one not to undergo a complete generative cycle. That shrub flowered abundantly and extensively, but it did not set fruits. As it was stated by CHYLARECKI \& Straus (1968), the incomplete generative develop- 
ment in shrubs of alien species is a result of their inadequate adaptation to Polish environmental conditions. However, a study by Przybora (1980) reported fruiting of another representative of that species in 1978 and 1979, thus S. oblata may not be classified as a species inadequately adapted to environmental conditions in Poland unless further studies are conducted to confirm that statement. The lack of seed setting may be caused by the different provenance of the analysed specimens.

As it was reported by ŁuKASIEWICZ (1989), during the catastrophically dry years of 1982 and 1983 with precipitation totals in Poznań amounting to $275 \mathrm{~mm}$ and $355 \mathrm{~mm}$, respectively, and mean annual temperature of $8.9^{\circ} \mathrm{C}$ and $9.4^{\circ} \mathrm{C}$, representatives of the genus Syringa, except for S. yunnanensis, did not suffer drastically enough to be classified to the group of plants with the lowest drought resistance. Among the species discussed in this study S. komarowii, S. meyeri, S. oblata, S. reticulata, S. tomentella and S. wolfii were included by Łukasiewicz in the group of trees and shrubs of medium drought resistance, i.e. such, in which as a result of adverse conditions leaves dry partly or even completely, while most shoots suffer no damage. In the course of investigations conducted in 2015 at the precipitation total of $402.8 \mathrm{~mm}$ and mean annual temperature of $10.2^{\circ} \mathrm{C}$ no premature leaf shedding or shoot die-back were observed. The dates for the onset of leaf shedding did not diverge considerably from the results given by PrzYBora (1980) and MiernicZAK (1988), whose studies were conducted in cooler years and those with greater precipitation totals. As it was reported by ŁABANOwSKI et al. (2001), non-infectious leaf spot as a manifestation of soil water shortage was not observed. Thus the examined lilacs withstand (with no deterioration of foliage decorative value) such atmospheric conditions as those in 2015 , in which precipitation $(402.8 \mathrm{~mm}$ ) was much lower than the mean from the last decade (481.4 mm) and the mean from the years 1971-2000

Table 4. Dates of phenological symptoms for phases of vegetative development in 2015

\begin{tabular}{|c|c|c|c|c|c|c|c|c|}
\hline \multirow{2}{*}{ Species } & \multicolumn{8}{|c|}{ Phases of leaf development } \\
\hline & 1 & 2 & 3 & 4 & 5 & 6 & 7 & 8 \\
\hline S. komarowii & 24.03 & 24.04 & 16.09 & 30.09 & 12.10 & $*$ & 23.09 & 23.10 \\
\hline S. meyeri & 3.03 & 14.04 & 6.10 & 12.10 & 22.10 & $*$ & 16.10 & 5.11 \\
\hline S. microphylla & 3.03 & 14.04 & 9.09 & 23.09 & 2.10 & $*$ & 6.10 & 27.10 \\
\hline S. oblata & 6.03 & 17.04 & 2.10 & 12.10 & 22.10 & $*$ & 22.10 & 11.11 \\
\hline S. reticulata & 9.03 & 14.04 & 14.09 & 5.10 & 12.10 & $*$ & 29.09 & 28.10 \\
\hline S. tomentella & 24.03 & 24.04 & 6.10 & 16.10 & 20.10 & $*$ & 6.10 & 27.10 \\
\hline S. wolfii & 3.03 & 10.04 & 28.09 & 1.10 & 6.10 & $*$ & 6.10 & 20.10 \\
\hline
\end{tabular}

Numbers: 1-8 correspond to development phases described in Study area, Material and Methods; *phase not found in analysed lilacs.

Table 5. Dates of phenological symptoms for phases of flower development in 2015

\begin{tabular}{|c|c|c|c|c|c|c|c|}
\hline \multirow{2}{*}{ Species } & \multicolumn{7}{|c|}{ Phases of flower development } \\
\hline & 9 & 10 & 11 & 12 & 13 & 14 & 15 \\
\hline S. komarowii & 28.04 & 21.05 & 25.05 & 1.06 & 6.06 & 2.06 & 11.06 \\
\hline S. meyeri & 10.03 & 6.05 & 11.05 & 20.05 & 25.05 & 14.05 & 29.05 \\
\hline S. microphylla & 27.03 & 14.05 & 19.05 & 29.05 & 3.06 & 20.05 & 8.06 \\
\hline S. oblata & 14.04 & 27.04 & 28.04 & 5.05 & 14.05 & 5.05 & 18.05 \\
\hline S. reticulata & 21.04 & 11.06 & 15.06 & 16.06 & 29.06 & 25.06 & 9.07 \\
\hline S. tomentella & 24.04 & 20.05 & 25.05 & 1.06 & 6.06 & 2.06 & 10.06 \\
\hline S. wolfii & 14.04 & 14.05 & 20.05 & 29.05 & 3.06 & 6.06 & 8.06 \\
\hline
\end{tabular}

Numbers: 9-15 correspond to development phases described in Study area, Material and Methods.

Table 6. Dates of phenological symptoms for phases of fruit development in 2015

\begin{tabular}{lcccccc}
\hline \multirow{2}{*}{ Species } & \multicolumn{7}{c}{ Phases of fruit development } \\
\cline { 2 - 7 } & 16 & 17 & 18 & 19 & 20 & 21 \\
\hline S. komarowii & 12.08 & 17.08 & 23.09 & 20.08 & 16.09 & 30.09 \\
S. meyeri & 24.07 & 28.07 & 7.08 & 6.08 & 11.08 & $* *$ \\
S. microphylla & 1.09 & 12.10 & 1.11 & 19.10 & 22.10 & $* *$ \\
S. oblata & $*$ & $*$ & $*$ & $*$ & 25.11 & $*$ \\
S. reticulata & 27.10 & 11.11 & 25.11 & 19.11 & 20.10 & $* *$ \\
S. tomentella & 6.08 & 1.09 & 21.09 & 25.08 & $*$ & $* *$ \\
S. wolfi & 6.08 & 14.08 & 10.09 & 14.08 & 23.09 & $* *$ \\
\hline
\end{tabular}

Numbers: 16-21 correspond to development phases described in Study area, Material and Methods; *lilac did not set fruits; **dispersal was extended to the following year. 
of $507 \mathrm{~mm}$ (PuŁYK 2009). Thus the analysed species may be successfully used in various garden designs in Poznań and the entire Wielkopolska region with no need for irrigation systems.

The species of high decorative value thanks to autumn foliage include S. meyeri (Fig. 5), S. microphylla (Fig. 6) and S. oblata (Fig. 7). They may be recommended for home gardens and urban green areas as elements of colourful vegetation compositions. It also needs to be stressed here that the above-mentioned lilacs do not lose their decorative foliage colour before leaf shedding. As it was reported by GóRKA (2003), in the United States considerable interest is observed in species of attractive autumn foliage and this trend is also reaching Poland. This is reflected in the tables of trees and shrubs of decorative value in autumn, presented in the plant catalogue recommended by the Polish Nurserymen Association (FILIPCZAK 2011).

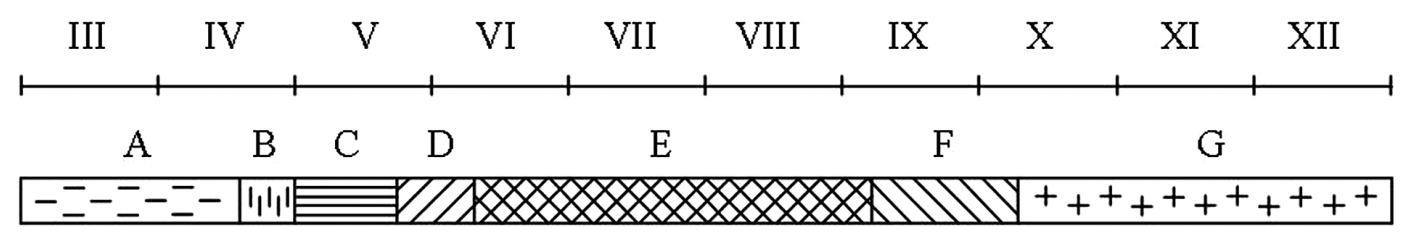

a
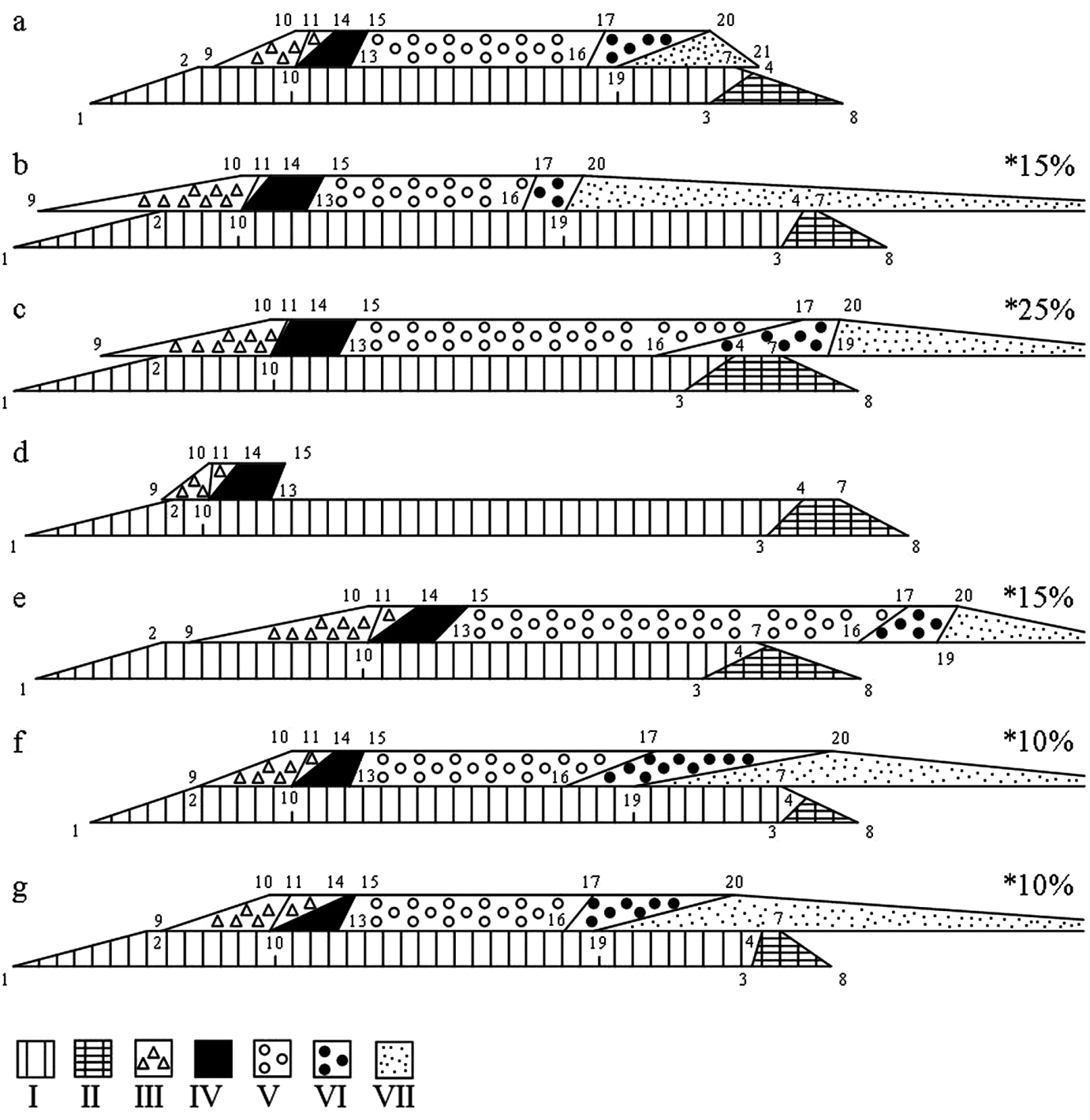

Fig. 3. Phenological spectra: Syringa komarowii (a), S. meyeri (b), S. microphylla (c), S. oblata (d), S. reticulata (e), S. tomentella (f) and S. wolfi (g). Numbers: 1-21 correspond to development phases described in Study area, Material and Methods and the numbers of development phases given in Tables 4, 5 and 6 . A - beginning of spring, B - early spring, C - full spring, D - early summer, E - summer, F - early autumn, G - autumn; stages: I - foliation, II - autumn leaf coloration and leaf-fall, III - inflorescence buds, IV - flowering, V - immature fruits, VI - mature fruits, VII - seed dispersion; * - percentage of the seeds left on the bush 


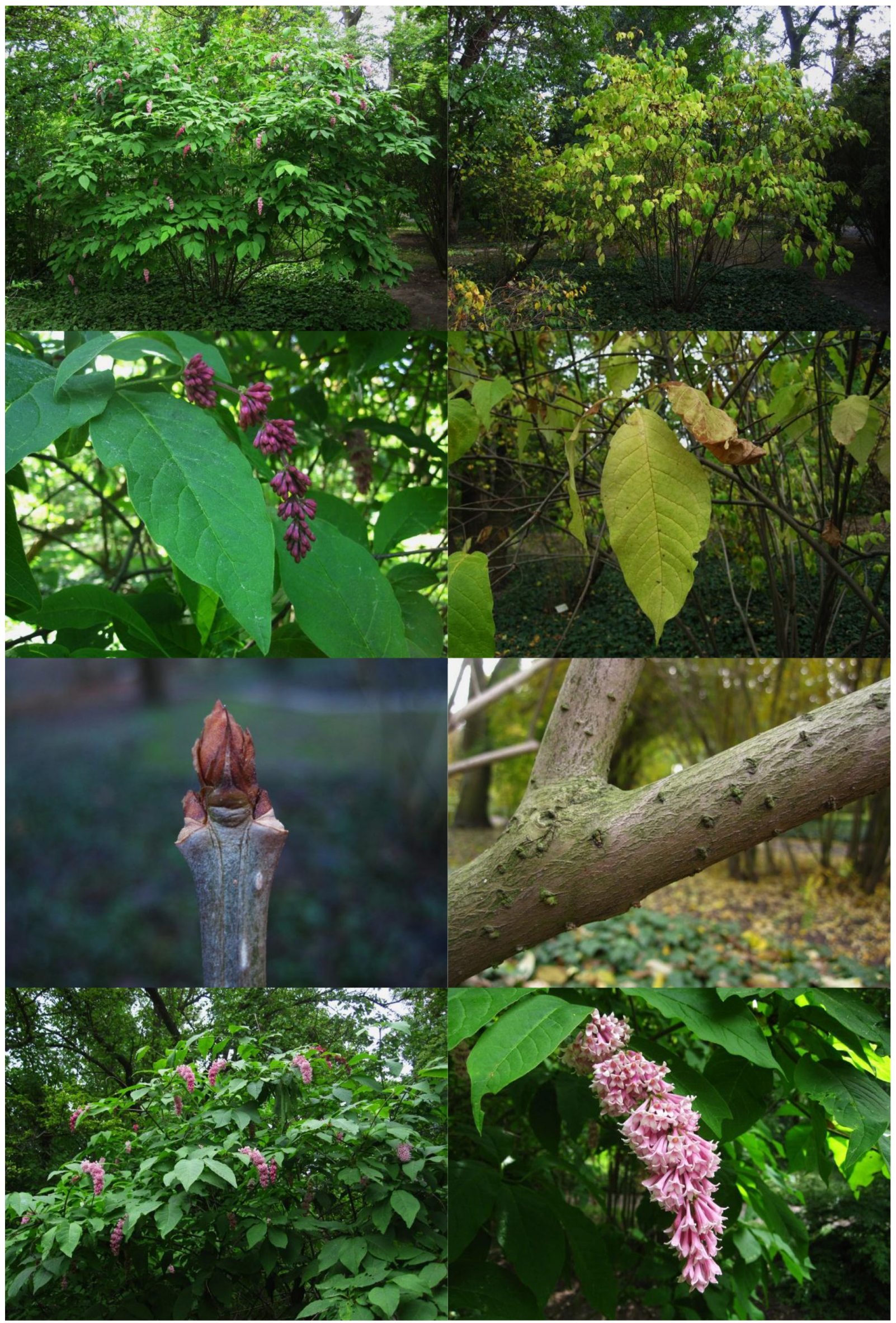

Fig. 4. Habit, leaves, buds, outer bark and inflorescences of Syringa komarowii 


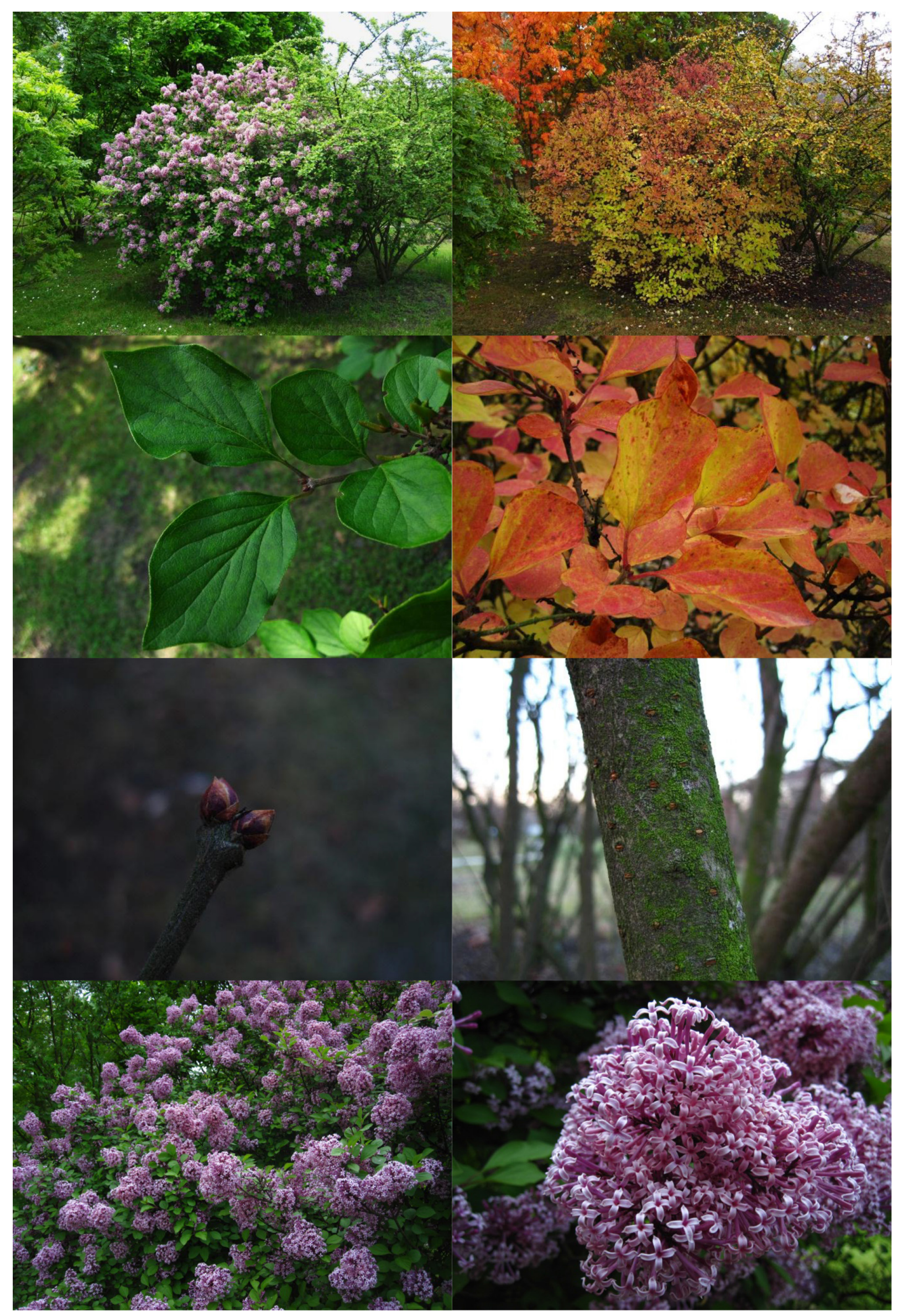

Fig. 5. Habit, leaves, buds, outer bark and inflorescences of Syringa meyeri 


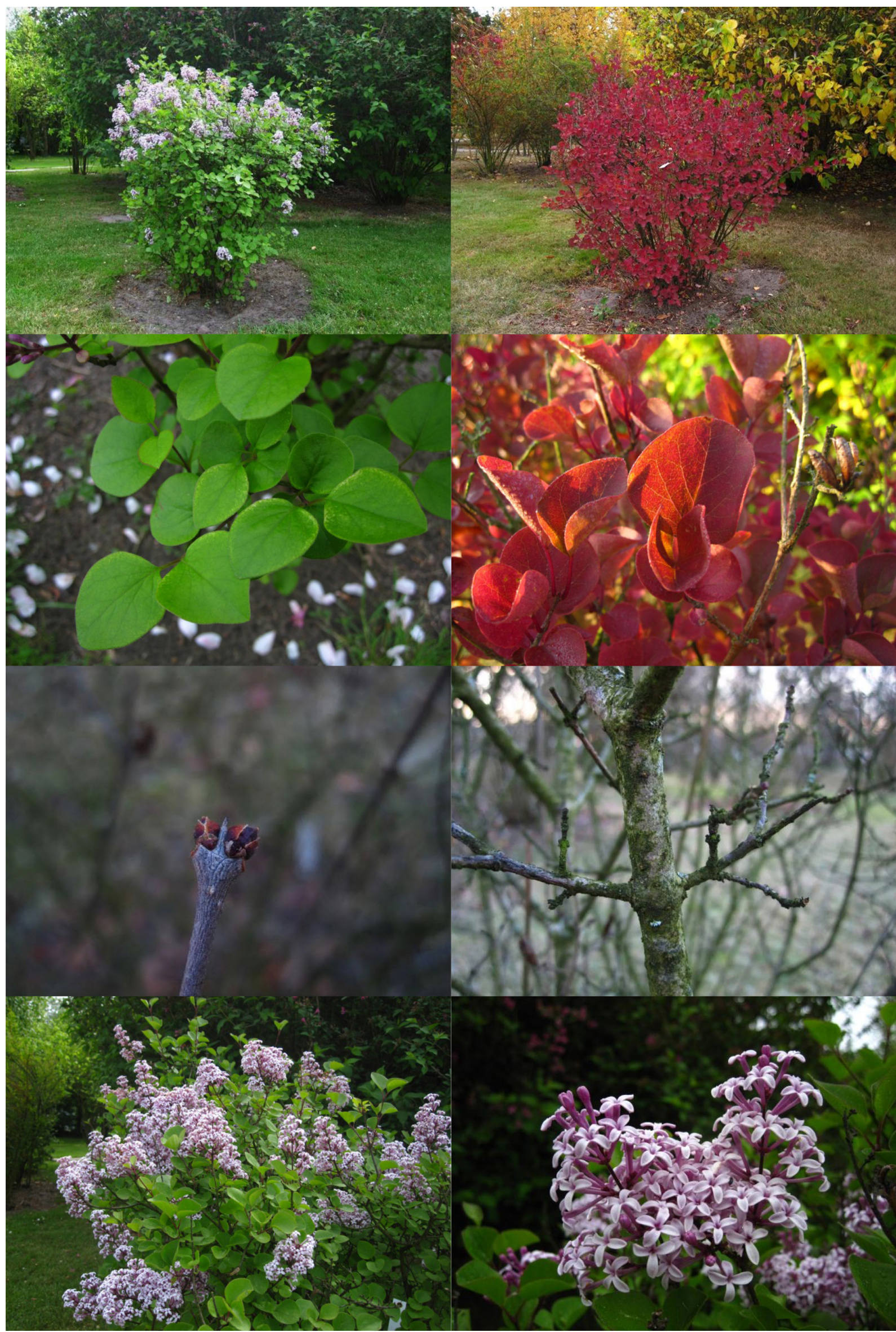

Fig. 6. Habit, leaves, buds, outer bark and inflorescences of Syringa microphylla 


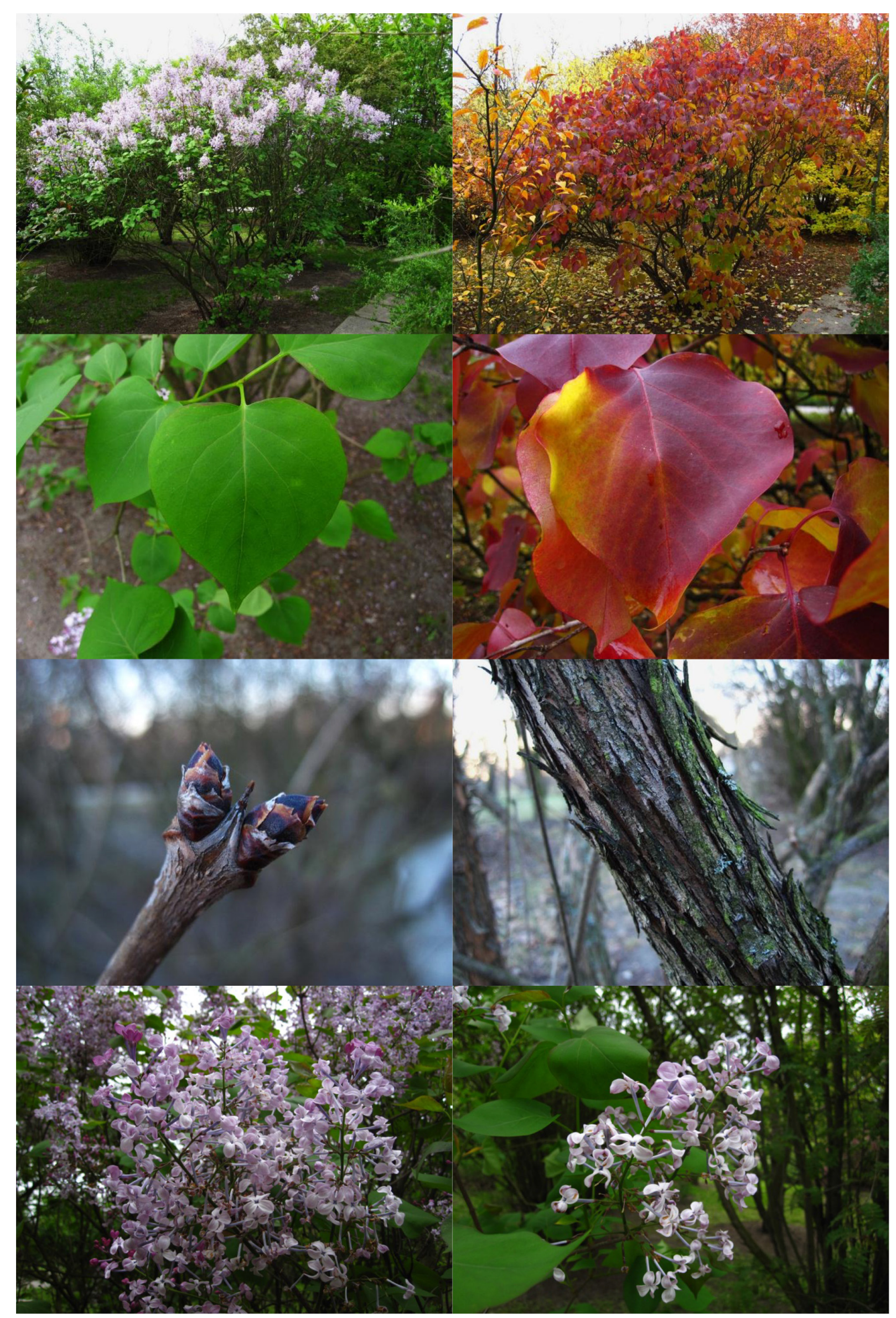

Fig. 7. Habit, leaves, buds, outer bark and inflorescences of Syringa oblata 


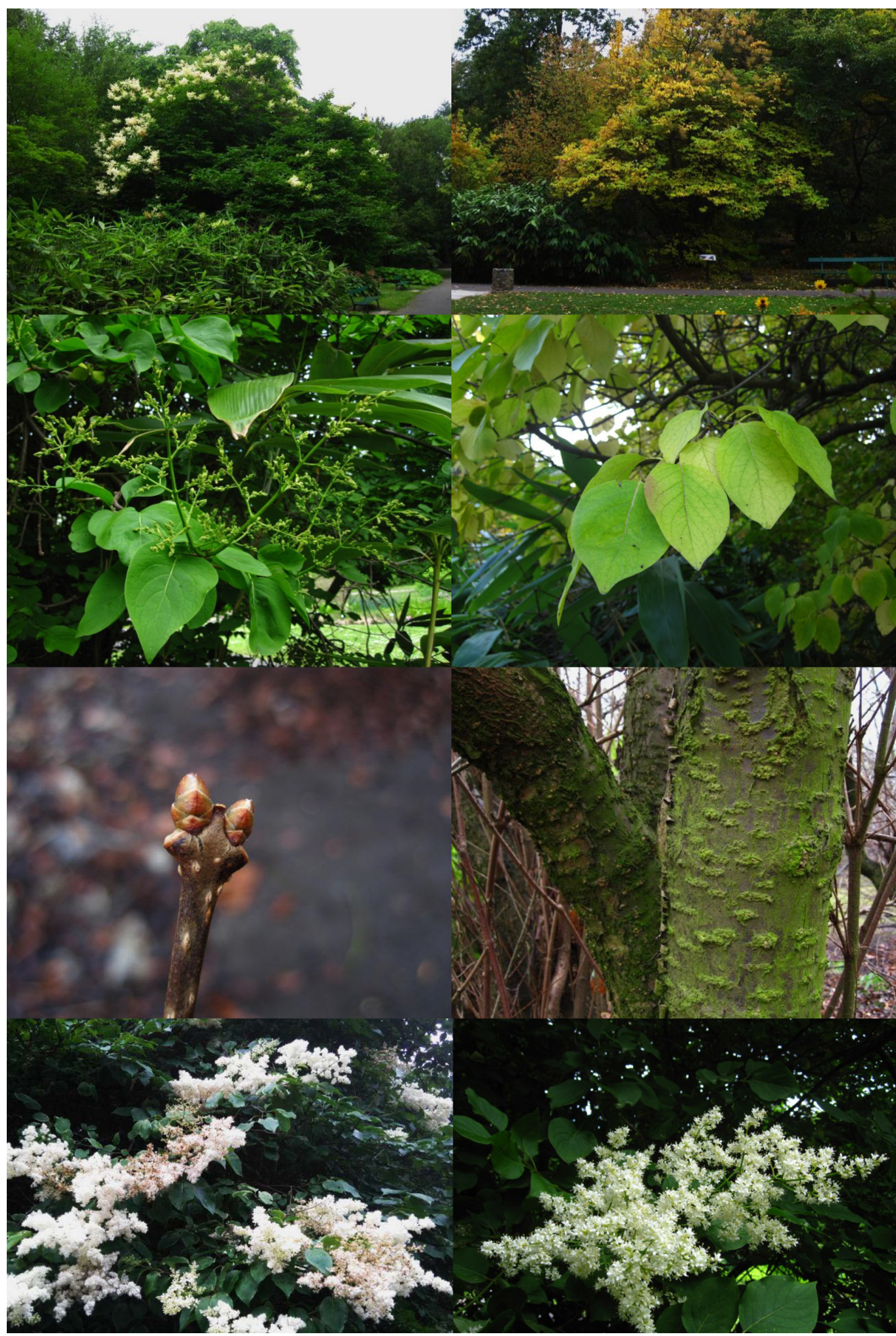

Fig. 8. Habit, leaves, buds, outer bark and inflorescences of Syringa reticulata 


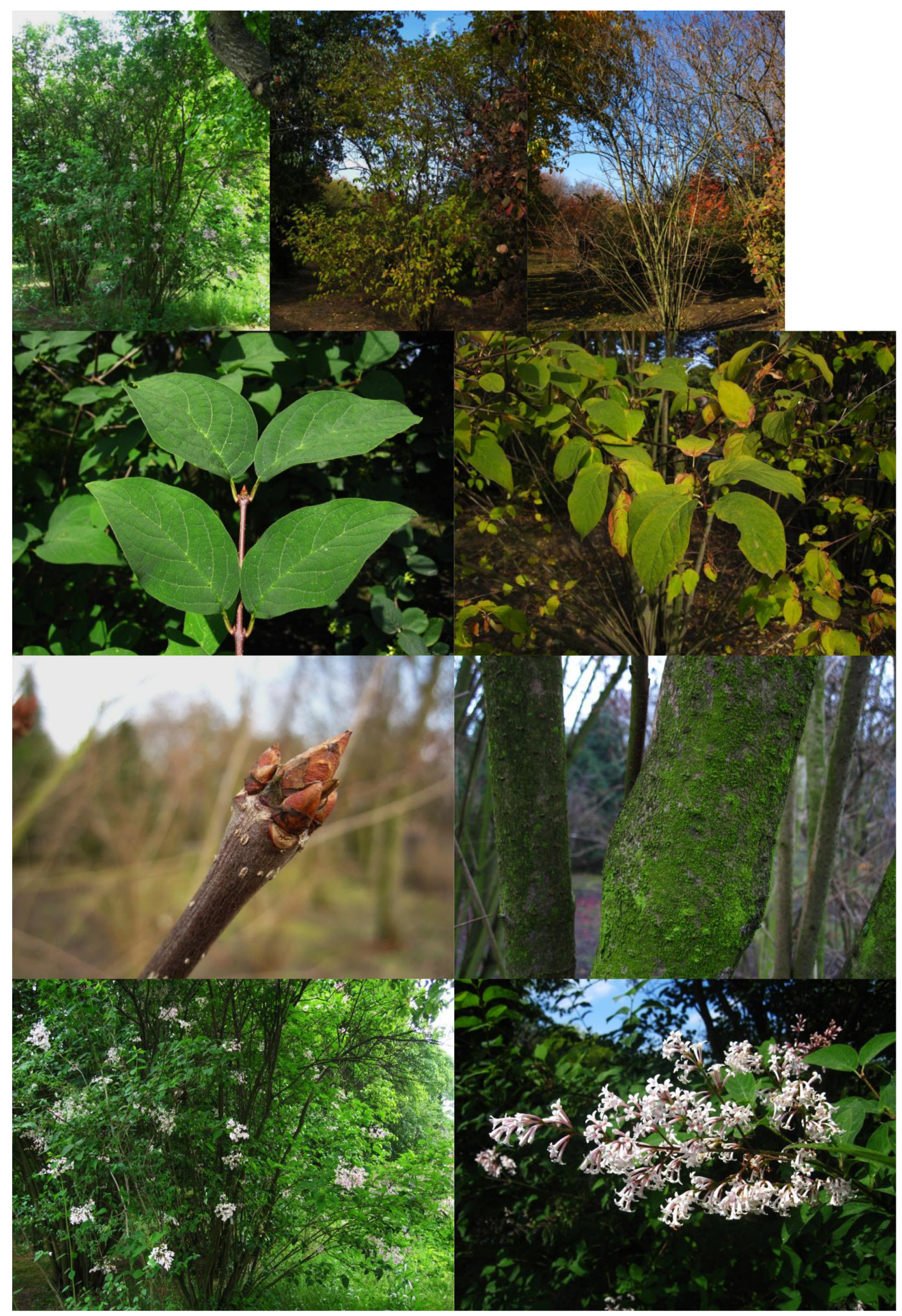

Fig. 9. Habit, leaves, buds, outer bark and inflorescences of Syringa tomentella 


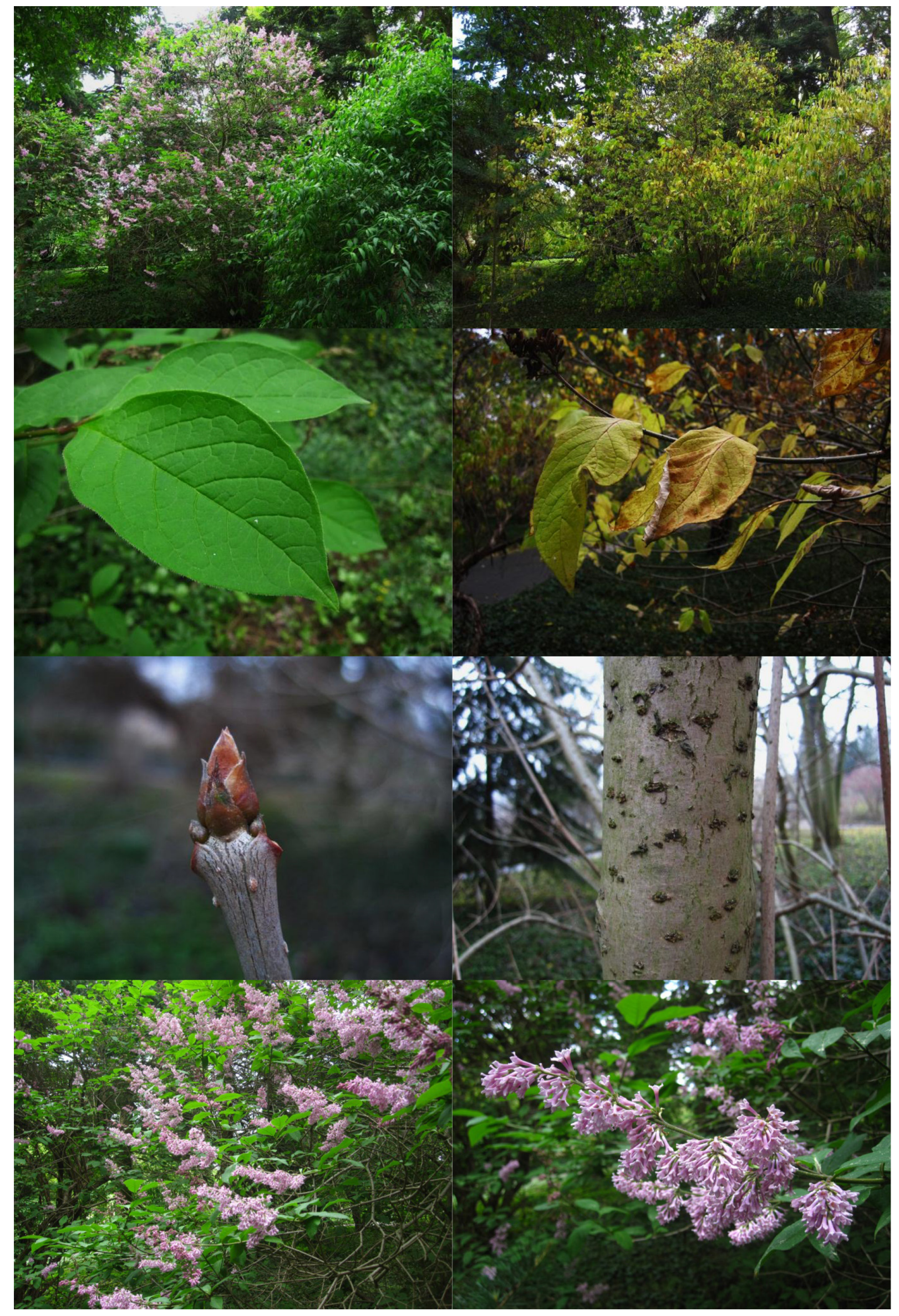

Fig. 10. Habit, leaves, buds, outer bark and inflorescences of Syringa wolfii 
Among the analysed species $S$. wolfii was the only one, on which European mistletoe Viscum album was found. The shrub was a host for four mistletoe specimens, of which two largest had eight branches and a diameter of $70 \mathrm{~cm}$ and nine branches and a $50 \mathrm{~cm}$ diameter, respectively. Both BoJARCZUK (1971) and STYPIŃSKI (1997) in their studies mentioned S. reticulata subsp. amurensis as the only host for mistletoe in the genus Syringa. Susceptibility of S. wolfii may result from the weakening of the shrub, growing in the collection of the Botanical Garden already since 1949. Classification of the species as a host of mistletoe is a negative trait in the case of plant selection for urban green areas, where trees and shrubs very often grow under stress conditions.

Syringa oblata was the only one among the observed species, which in the vegetation season produced suckers. As it was reported by ВіАєОВок \& Hellwig (1955) and Bugata (2000), it is a species similar to $S$. vulgaris, capable of forming dense thickets. Depending on the plant use, this property may be a disadvantageous or advantageous characteristic. In the case of home gardens and allotment plots the use of S. oblata will require additional tending operations connected with appropriate management of the shrubs. When plants are selected to reinforce escarpments, production of suckers by trees and shrubs is desirable. Syringa vulgaris is one of the many species recommended for that purpose by ZAJACZKOWSKI (2001), while these observations indicate that a similar function may also be served by $S$. oblata.

\section{CONCLUDING REMARKS}

1. The longest foliation phase was observed in $S y$ ringa oblata (251 days) and S. meyeri (248 days).

2. Lilacs which bloomed for the longest time were S. reticulata (29 days), as well as S. microphylla and S. wolfii (26 days).

3. Species characterised by the longest period in bloom included S. oblata (21 days) and S. microphylla (16 days).

4. Syringa komarowii, S. meyeri, S. microphylla, S. oblata and $S$. reticulata were considered to be the most valuable and recommendable for green areas. Among the above-mentioned the most attractive in terms of autumn foliage were S. meyeri, S. microphylla and S. oblata.

5. Syringa komarowii is the lilac with exceptionally large and attractive leaf blades in comparison to the others.

6. Syringa microphylla, S. oblata and S. reticulata are recommendable thanks to their long flowering period. Moreover, the species characterised by especially decorative inflorescences include $S$. komarowii (with particularly decorative, pendulous panicles) and S. meyeri (with very dense and fine panicles).
7. In large garden planting compositions S. komarowii, S. oblata and S. reticulata are most suitable thanks to their stronger growth in comparison to the other species. In turn, S. meyeri and S. microphylla are better suited for smaller spaces.

\section{ACKNOWLEDGEMENTS}

The publication were supported by the Department of Botany, the Poznan University of Life Sciences.

\section{REFERENCES}

Bąbelewski P. (2009): Lilaki. Działkowiec 5: 8-11.

BiaŁoвоK S. (1971): O naukowej i praktycznej roli badań fenologicznych $\mathrm{w}$ ogrodach botanicznych i arboretach. In: S. Pieniążek (ed.). Fenologia i jej praktyczne wykorzystanie. Materiały z obrad Zjazdu Fenologicznego. Kraków, 15-16 czerwca 1970. Zeszyty Problemowe Postępów Nauk Rolniczych 120: 83-91.

BiaŁobok S., Hellwig Z. (eds) (1955): Drzewoznawstwo. PWRiL, Warszawa.

Bielawska A., Czubińska M., Górska M., Wolska K. (1964): Obserwacje fenologiczne nad drzewami i krzewami aklimatyzowanymi w Ogrodzie Botanicznym Uniwersytetu im. Adama Mickiewicza w Poznaniu w latach 1957-1961. PWN, Poznań.

BojARCZUK T. (1971): Żywiciele jemioły pospolitej (Viscum album L.) w Polsce. Rocznik Sekcji Dendrologicznej Polskiego Towarzystwa Botanicznego 25: 189-203.

Bugaza W. (2000): Drzewa i krzewy. PWRiL, Warszawa.

Chylarecki H., Straus H. (1968): Wyniki dziesięcioletnich obserwacji fenologicznych nad drzewami i krzewami w Arboretum Kórnickim. Arboretum Kórnickie 13: 37-120.

CZEKAlski M. (2014): Lilak japoński. Szkółkarstwo 4: 34-35.

FiLIPCZAK J. (ed.) (2011): Katalog roślin: drzewa, krzewy, byliny polecane przez Związek Szkółkarzy Polskich. Agencja Promocji Zieleni, Warszawa.

GóRKA W. (2003): Sprzedać kolor. Szkółkarstwo 5: $14-17$.

Łabanowski G., Orlikowski L., Soika G., WojdyŁa A. (2001): Ochrona ozdobnych krzewów liściastych. Wydawnictwo Plantpress, Warszawa.

ŁUKASIEWICZ A. (1984): Potrzeba ujednolicenia metodyki fenologicznej w polskich ogrodach botanicznych i arboretach. Wiadomości Botaniczne 28, 2: 153-158.

ŁUKASIEWICZ A. (1989): Wpływ katastrofalnej suszy w latach 1982 i 1983 na drzewa i krzewy w Ogrodzie Botanicznym UAM i na terenie miasta Poznania. Part 1, 2. Wiadomości Botaniczne 33, 2: $21-52$. 
ŁuKASIEwicz A. (1995): Dobór drzew i krzewów dla zieleni miejskiej środkowo-zachodniej Polski. Wydawnictwo Naukowe UAM, Poznań.

ŁuKasiewicz A., GóRsKa-ZajączKowsKa M. (1983): Fenologiczne pory roku w Poznaniu w latach 19681979. Wiadomości Botaniczne 27, 1: 67-75.

MiERNICZAK J. (1988): Rytmika rozwojowa wybranych gatunków obcego pochodzenia z rodzaju Syringa w warunkach Ogrodu Botanicznego UAM w Poznaniu. Typescript. Adam Mickiewicz University in Poznań, Faculty of Biology, Poznań.

NAwrockA-GrześKowiak U. (1997): Niedoceniane gatunki lilaka. Szkółkarstwo 3: 22-23.

Przybora B. (1980): Rytmika sezonowa wybranych gatunków drzew i krzewów obcego pochodzenia w warunkach poznańskiego Ogrodu Botanicznego $z$ uwzględnieniem stopnia ich aklimatyzacji i walorów dekoracyjnych. Typescript. Adam Mickiewicz University in Poznań, Faculty of Biology and Earth Sciences, Poznań.

PuŁYк M. (ed.) (2009): Raport o stanie środowiska w Wielkopolsce w roku 2008. Biblioteka Monitoringu Środowiska. Poznań.

Seneta W., Dolatowski J. (2012): Dendrologia. Wydawnictwo Naukowe PWN, Warszawa.
SHENNikov A.P. (1928): Fenologicheskiye spektry rastitel'nykh soobshchestv. Sb. «Trudy Vologodskoy sel'skokhozyaystvennoy opytnoy stantsii», vyp. 2, Vologda: 5-21.

STYPIŃSKI P. (1997): Biologia i ekologia jemioły pospolitej (Viscum album, Viscaceae) w Polsce. PAN, Kraków.

TAKHTAJAn A. (2009): Flowering plants. Springer, New York.

WiткоwsкA B. (1984): Obserwacje fenologiczne wybranych gatunków drzew i krzewów w Wojewódzkim Parku Kultury i Wypoczynku w Chorzowie w latach 1974-1976. Part 1. Rocznik Dendrologiczny 35: 105-117.

ZajączKowski K. (ed.) (2001): Dobór drzew i krzewów do zadrzewień na obszarach wiejskich. Instytut Badawczy Leśnictwa, Warszawa.

For citation: Sowelo M., ANTKOWiAK W. (2017): Phenological observations of selected species from the genus Syringa L. (Oleaceae) in the Botanical Garden of the Adam Mickiewicz University in Poznań. Steciana 21(2): 69-83. doi: 10.12657/ steciana.021.008 